\title{
Preliminary assessment of preconditions to deliver carbon neutrality in apartment buildings by 2050
}

\author{
Lauri Lihtmaa ${ }^{1 *}$ and Targo Kalamees ${ }^{2,1}$ \\ ${ }^{1}$ Nearly Zero Energy Buildings Research Group, Tallinn University of Technology, Ehitajate tee 5, 19086 Tallinn, Estonia \\ ${ }^{2}$ Smart City Center of Excellence (Finest Twins), Tallinn University of Technology, Ehitajate tee 5, 19086 Tallinn, Estonia
}

\begin{abstract}
Member states of European Union have large stock of residential buildings that require urgent renovation in order to reach carbon neutrality by 2050. In our paper we provide a preliminary evaluation of preconditions of such goal within the context of shrinking regions. Our data originates form renovation subsidy database of large renovation programme managed by state fund and form Nation Statistical Bureau. First we estimate the potential of apartment buildings occupation within the next 30 years. We exclude buildings that are going to be abandoned due to the demographical and migration reasons. Next we calculate the potential of construction sector to deliver required amount of renovations. We observe that the in our case current renovation rate must at least be increased by factor of three in order to comply with the carbon neutrality goal. This, however, is very challenging because supply of renovations' construction is limited and overstimulated demand could increase construction prices significantly while rendering the effect of state incentives inefficient. Therefore an urgent technological change in renovation delivery is required to reach carbon neutrality goals.
\end{abstract}

\section{Introduction}

Carbon neutrality is one of the big challenges within the energy sector. To mitigate climate change it is necessary to transform energy consumption form fossil fuels to renewables and also conserve energy. As buildings require about $40 \%$ total energy produced in Europe (50\% in Estonia), it is obvious that there is a great potential for reducing energy demand. Energy performance of building directive (EPBD) [1] requires all new buildings to be nearly Zero Energy Buildings (nZEB) from 2020. However, in most of European countries, the majority of buildings stock was built after World War II mainly during the period with low requirements on energy performance. Therefore existing buildings include a large potential for energy performance improvement [2-6], especially in cold climate.

As reductions in $\mathrm{CO}_{2}$ emissions are generally proportional to the energy saving potentials [7] EPBD requires EU member states to renovate almost all buildings by 2050 in order to achieve carbon neutral economy. This significant challenge is addressed in long term energy efficiency strategies that are prepared by member states and presented to European Commission. In order to set renovation milestones for next decades we need to know which buildings and where to involve in renovation strategy.

In their literature review on energy performance of buildings during the operational stage Geraldi and Ghisi [8] showed that buildings' stock-level analysis has extensive potential to improve building performance analysis. Nägeli et al. [9] developed bottom-up building stock model of Switzerland and Sandberg et al. [10] modelled building stock in 11 European countries while showing that models can effectively reproduce the past development, current stock size and composition and the long-term dynamics in the system in an acceptable way.

It is clear that some buildings that are currently in use, will be left out of service by 2050 . On one hand this happens naturally by the buildings stock renewing process which speed is estimated about $1 \%$ per year and modern carbon neutral buildings will be built instead. However, there are important reasons why buildings could be abandoned before the end of their life cycle.

There are two major trends that affect the demand for buildings in the future. Firstly, we point out the urbanisation which leads to major restructuring of the location of population. Larger and economically diverse centres are growing (supported by erecting of new nZEB buildings) as the periphery shrinks. The growth of the stronger regions is fuelled at expense of weaker regions [11]. This trend amplifies the regional divide between core-periphery lines [12]. Secondly, European population is getting older and shrinks [13].

As the population declines there is less demand for buildings, especially in peripheral regions. It is evident that there is no rationale to include such buildings in renovation plan.

Current calculations of the amount of buildings that require renovation are done rather simply. For example the previous renovation reports in Estonia are based on total amount of surface area recorded in building registry

* Corresponding author: research@ecobon.ee 
$[14,15]$. Furthermore, building stock modelling has mostly applied in the context and expectation of population growth $[10,16]$. Those approaches ignore the effect of abandoned buildings in the future. More importantly, the calculations of carbon conservations targets are also based on this data which in turn could result in overestimated potential of energy and carbon reduction targets. However, abandoned buildings are not consuming energy and thus are not emitting carbon dioxide. This in turn renders the carbon goal more obtainable.

We would also like to point out that EPBD does not explicitly state that energy policy must address regional and social aspects. However, there are evidence that ignoring such aspects in policy application can have negative externalities which further exacerbates the social polarisation. For example recent studies show that renovation grants tend to distribute unequally between and within regions $[17,18]$.

Therefore we can argue that long term renovation strategies must also address migration and demographical trends in order to address carbon neutrality in cohesion with regional development.

The requirement of EPBD to renovate most of the building stock is such an ambitious goal that we can even question to what extent it is achievable. On one hand, boosting renovation activities require incentives and information dissemination. However, if the demand for engineers and builders grow, the prices also tend to rise, which in turn renders the incentives and grants inefficient. This could seriously hinder the achievement of carbon neutrality goal. Thus, the growth capacity of the building sector is of paramount importance and must be analysed while designing a renovation strategy.

The objective of this study is to assess how the buildings' renovation goal can be achieved in the context of urbanisation and population decline taking account the growth limits of construction sector. We employ the example of residential sector in Estonia and focus on the apartment buildings.

\section{Methodology}

In order to predict building stock for the preliminary assessment of the goal of climate neutrality of buildings by 2050 , we use the migration and demographic projections for forecasting the occupancy of existing buildings within the next 30 years, Fig 1 . We analyse what kind of preconditions are needed to deliver the renovations by building sector. Specifically we look into the dynamics of renovation demand and construction prices.

To give an estimation of apartment buildings renovation potential, we start by describing the current residential stock that is built before the year of 2000 $(n=22597)$. This is due to the reason that newer buildings are considered sufficiently energy efficient and we can use data form census of 2000 to compare with the data form building registry.
We use regional population forecast form National Statistical Bureau to estimate population change in counties $(n=15)$ in order to calculate future occupation of apartment buildings. There are five scenarios for population forecast [19] in Estonia for 2050. We use the base scenario which is considered the most probable. For comparison reasons we also make rough estimations with more positive and more pessimistic scenario. As official population forecast is only addressing years till 2045, we used linear extrapolation to fit the forecast for EU carbon neutrality target of 2050 .

To further specify the effects of regional population migration we use the results form commuting studies also prepared by National Statistical Bureau. We assume that if a region is shrinking, population is moving from smaller and economically weaker places to larger centres. This assumption is compliant with urbanisation and migration trends [20,21].

Next, we analyse the amount and regional distribution of new builds by utilising building permits form national buildings registry. Doing so we are able to assess the demand for new apartments and evaluate the capacity of construction sector in different regions.

Next, we look to what extent construction prices for renovations have changed during the period of 2010 and 2019. This period is selected because at that time Estonia has introduced an comprehensive subsidy programme to accelerate renovation activities [22]. Therefore, there is an exhaustive database readily available to analyse technical, economic and spatial dynamics of energy renovations. We only include buildings that have implemented deep energy renovations $(n=609)$.

Next, we compare renovation cost dynamics against apartment buildings' construction price index in order to understand if the role of stimulated renovation demand has caused renovation costs to increase more than natural growth. Informal interviews with representatives of construction companies $(n=3)$ are used to interpret the results.

We use MS Excel for statistical analysis and ArcGis software for spatial analysis.

We would like to point out that this study is a preliminary assessment and therefore we are yet unable to forecast which types of apartment building are going to be abandoned. At the time our contribution is sufficient for broader energy renovation strategy. However, for the regional application more specific analysis is required.

We acknowledge that renovation volume has been hindered also by renovation barriers such as mistrust, lack of social and financial capital, lack of motivation, information asymmetry. which have been addressed in numerous papers previously [23-27]. Instead we focus on the renovations delivery. 


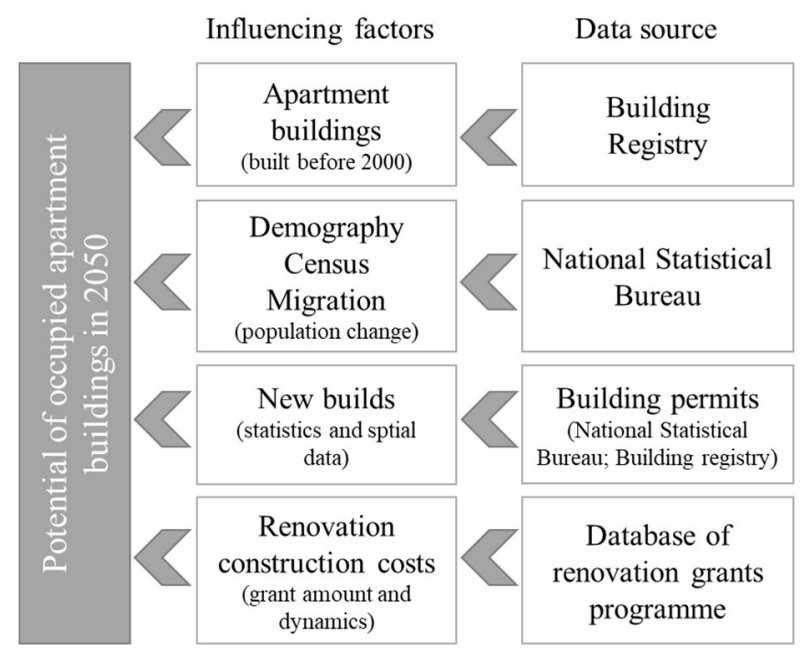

Fig 1. Influencing factors and data source to determine potential of renovations by 2050 .

\section{Results and discussion}

\subsection{Apartment buildings according to existing database}

Apartment buildings account for $51 \%\left(34282 \times 10^{3} \mathrm{~m}^{2}\right)$ of the total net area of dwellings in Estonia. According to the 2000 census, $70 \%$ of people (i.e. 931,000 persons) lived in apartments. The most active construction period was $1961-1990$, when about $79 \%$ apartment buildings were construed [28]. Dominating construction types for apartment buildings are brick and concrete (Fig 2). In total, there are about 22.6 thousand apartment buildings in building registry that are built before 2000. As a rule, dwellings in peripheral areas are older. Today the designed service life of older apartment buildings is close to the end which could lead to hazardous situations and therefore urgent intervention is needed.

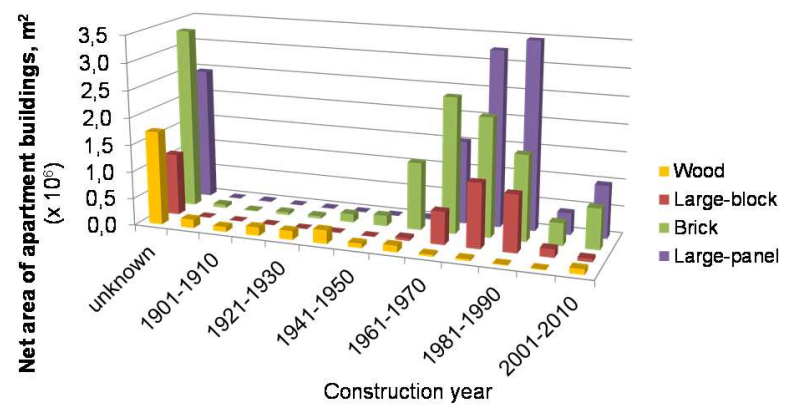

Fig 2. Distribution of apartment buildings by the net area and by the construction types in Estonia [29].

\subsection{Occupation of apartment buildings in $\mathbf{2 0 5 0}$}

The apartment building forecast depends on construction of new buildings and decline of existing buildings. Both parameters are influenced by demand which in turn depend strongly on population change.

Within last decade the average rate of new apartment buildings is 150 per year. New apartment buildings have mostly concentrated in capital region of Harju County and in southern centre of Tartu County. Those are the regions, which grow and also have gained most renovation subsidies form state's renovation programme during the last decade [30].

The main scenario of population forecast for 2050 estimates 3.5 percent decrease of residents. However, inner state migration shows that only two counties grow at the expense of others (Table 2). This means that a significant amount of apartment buildings are going to be abandoned within next decades. Our calculations show that 5322 apartment buildings which makes 17.1 percent of current total surface area, will be left out of service by 2050 (Table 2).

National Statistical Bureau's population forecast also includes more positive and pessimistic scenario which results about 4000 and 6000 of abandoned apartment buildings respectively. We can observe that those scenarios have little effect on the occupation change of apartment buildings compared to main scenario. This is because the impact of overall population decline is marginal compared to inner state migration which bases on the urbanisation and regional change principles.

In conclusion, the amount of apartment buildings that require extensive renovation is about 14.5 thousand which includes $64 \%$ of current apartment buildings stock (Table 1).

Table 1. Renovation potential forecast by 2050

\begin{tabular}{lr} 
& No of buildigs \\
\hline Apartment buildings (built before 2000) & 22600 \\
Renovated using subsidy programme (2010-2019) & 1100 \\
Renovated without of any subsidy (2000-2019) & 2000 \\
Building abandonment by 2050 & 5000 \\
Total renovation need by 2050 & $\mathbf{1 4 5 0 0}$
\end{tabular}


Table 2. Forecast of population and occupation change in apartment buildings by 2050 .

\begin{tabular}{|c|c|c|c|c|c|}
\hline \multirow[t]{2}{*}{ Region } & \multirow{2}{*}{$\begin{array}{c}\text { Population } \\
\text { change } \\
(\%)\end{array}$} & \multicolumn{2}{|c|}{$\begin{array}{l}\text { Current stock of apartment buildings } \\
\text { (built before 2000) }\end{array}$} & \multicolumn{2}{|c|}{$\begin{array}{l}\text { Abandondment of apartment buildings } \\
\text { (by 2050) }\end{array}$} \\
\hline & & No of buildings & $\begin{array}{c}\text { Net area } \\
\text { (thousand } m^{2} \text { ) }\end{array}$ & No ofbuildings & $\begin{array}{c}\text { Net area } \\
\left.\text { (thousand } m^{2}\right)\end{array}$ \\
\hline Harju county & 22.4 & 8055 & 12956 & -56 & -47 \\
\hline Hiiu county & -22.2 & 159 & 114 & -82 & -59 \\
\hline Ida-Viru county & -43.4 & 2140 & 4230 & -1068 & -1672 \\
\hline Jõgeva county & -39.2 & 688 & 559 & -374 & -269 \\
\hline Järva county & -40.6 & 764 & 715 & -453 & -365 \\
\hline Lääne county & -32.9 & 521 & 489 & -185 & -165 \\
\hline Lääne-Viru county & -33.9 & 1486 & 1361 & -599 & -499 \\
\hline Põlva county & -33.6 & 458 & 428 & -221 & -167 \\
\hline Pärnu county & -18.5 & 2111 & 1605 & -540 & -376 \\
\hline Rapla county & -22.9 & 651 & 564 & -284 & -237 \\
\hline Saare county & -20.3 & 540 & 454 & -193 & -134 \\
\hline Tartu county & 5.8 & 2476 & 2803 & -126 & -83 \\
\hline Valga county & -39.7 & 596 & 582 & -262 & -208 \\
\hline Viljandi county & -32.8 & 1265 & 881 & -575 & -356 \\
\hline Võru county & -29.9 & 687 & 638 & -304 & -224 \\
\hline Grand Total & & 22597 & 28378 & -5322 & -4861 \\
\hline
\end{tabular}

\subsection{Capacity of construction sector}

Typical energy renovation includes additional thermal insulation (typically onsite construction) of walls (15 $20 \mathrm{~cm})$ and roof $(30-40 \mathrm{~cm})$, replacing windows, installing new heating system and mechanical ventilation system with heat recovery [31-33]. In Estonia there are about 200 deep energy renovations per year. Continuous motivation of apartment associations to renovate their buildings combined with renovation grant [22] has resulted increased demand for construction works year by year.

National Statistics show that the construction price index has increased 15 percent during the years of 20112019. At the same time our analysis of renovation subsidy programme shows that renovation costs have increased 59 percent. While the average renovation cost in 2015 was $247 € / \mathrm{m}^{2}$, it has increased to $297 € / \mathrm{m}^{2}$ in 2017 [34].

Table 3. Renovation cost dynamics in 2010-2019

\begin{tabular}{cccc} 
Year & $\begin{array}{c}\text { Count of } \\
\text { subsidised } \\
\text { renovations }\end{array}$ & $\begin{array}{c}\text { Renovation } \\
\text { cost chage in } \\
\text { year (\%) }\end{array}$ & $\begin{array}{c}\text { Construction price } \\
\text { index change in } \\
\text { year (\%) }\end{array}$ \\
\hline 2010 & 1 & - & - \\
2011 & 21 & 16.4 & 3.3 \\
2012 & 89 & 11.2 & 4.2 \\
2013 & 65 & 11.2 & 4.4 \\
2014 & 22 & 16.6 & 0.3 \\
2015 & 16 & 2.5 & -0.8 \\
2016 & 79 & 10.1 & -0.6 \\
2017 & 139 & 13.9 & 1.0 \\
2018 & 106 & 6.2 & 2.7 \\
2019 & 71 & 11.0 & 1.8
\end{tabular}

This shows that state stimulations are increasing the demand for renovations faster than construction sector is able to grow. Yearly change of construction index and renovation costs are illustrated in table 3.

Our results do not consider that carbon neutrality goal also includes the renovation of other types of buildings such as commercial, education and administrative buildings. This means that the demand for construction delivery is even higher, thus rendering the challenge of climate change combat more difficult to achieve.

Construction companies have testified that using current laborious technics they are unable to double the renovation delivery. Our calculations show that in average the renovation delivery must be increased by threefold. Therefore, we can argue that using current technology, construction sector is unable to deliver renovations in significantly increased rate in the future.

\subsection{Preconditions for carbon neutrality}

Combining the previously given results with informal interviews with the stakeholders of construction sector, we can conclude next preconditions for carbon neutrality goal for apartment buildings

Firstly, it is clear that current pace and the capacity of growth of construction sector in insufficient to deliver carbon goals. Virtually all renovations are bulky handcraft which is slow and expensive due to the labour costs. Therefore technological change form manual built to prefabricated renovation is required.

\footnotetext{
* Corresponding author: research@ecobon.ee
} 
Secondly, in order to increase the productivity of designers, standardised solutions especially for large building estates should be used. This in turn raises the productivity of offsite renovation and production companies.

Third precondition is sufficient and consistent financial support for carbon neutrality renovation. State support is required to start pilot projects of prefabricated panels and to encourage early adopters to choose new solutions. Although first pilots of prefabrication are tested, we suggest to continue with this practice in order to develop engineering and construction skills as well to introduce the solution for customers. Support can be reduced when prefabrication has mainstreamed and the costs have reached desired equilibrium.

Prefabrication requires constant demand in order for the sector to be sustainable. Therefore, state support should be readily available in order to stimulate the demand within recessions of economic cycles. Prefabrication technology can also be applied for export as there are similar buildings especially in other postsoviet member states. However, for the smaller, custom and heritage apartment buildings prefabrication possibilities are limited and thus we need further research on how productivity can be increased in such cases.

Fourth precondition addresses the context of regional disparities. Communities in growing centres are more capable to renovate than in smaller places and especially in shrinking regions and periphery [17]. Therefore, limited state support for renovations should be distributed between regions differently. Larger centres where marketbased development prevails, state support should be used for project management and consultations to ensure the quality of renovations. Novel solutions that promote productivity can also be eligible for support. Although there is no rationale for carbon neutral renovations in shrinking regions, those buildings also require some renovations. State support should be used in cases which present unsafe building usage and show dangers for occupants' health.

The major target group for renovation support are regional and local centres which are key importance in settlement structure. If those places have market barriers for energy renovations, it is reasonable for the state to stimulate renovation demand and support also direct construction costs.

Current study concentrates on apartment buildings. The second large dwelling type, detached house, should not be overlooked. Those buildings are also significant, both in their ubiquity and energy consumption. Csoknyai showed that detached houses are responsible for $50-80 \%$ of the total primary energy demand of the housing stock, depending on the country [35].

\section{Conclusions}

Achieving carbon neutrality in buildings is an important and difficult challenge within next three decades. On the one hand, shrinking regions cause the reduction of residential buildings that are occupied in next decades, thus reducing the overall renovation demand. However, our study shows that current renovation rate is still insufficient and needs to be increased by several times to deliver the required amount of renovations by 2050 .

Clearly, government incentives such as grants and tax rebates are effective measures to boost renovation activities within communities. Such stimulations in turn could cause the significant construction price growth due to the rising demand and thus render the incentives inefficient while also hindering the renovations in vulnerable regions. Our case study shows that renovation demand has increased construction costs at least by factor of two.

We also note, that non-residential buildings must be also upgraded to meet carbon goals. Furthermore, overall construction demand increases also due to the urbanisation and regional migration which causes the increased demand for new builds. Therefore, as our case shows, carbon goals could only be achieved by technological change that results of significant increase in engineering and construction productivity.

This research was supported by the Estonian Research Council (grant No. PRG483) and Estonian Centre of Excellence in Zero Energy and Resource Efficient Smart Buildings and Districts, ZEBE (grant No. 2014-2020.4.01.15-0016) funded by the European Regional Development Fund, and by the European Commission through the H2020 projects Finest Twins (grant No. 856602) and NERO (grant No. 754177).

\section{References}

1. Directive (EU) 2018/844, Off. J. Eur. Union, L 156, 19.6.2018 75 (2018)

2. Ü. Alev, A. Allikmaa, and T. Kalamees, in Energy Procedia (2015), pp. 907-912

3. J. Rose, K. E. Thomsen, O. C. Mørck, K. Kuusk, and T. Kalamees, ASHRAE Trans. 122, 58 (2016)

4. T. Prasauskas, D. Martuzevicius, T. Kalamees, K. Kuusk, V. Leivo, and U. HaverinenShaughnessy, Energy Procedia 96, 253 (2016)

5. K. Kuusk and T. Kalamees, Energy Procedia 78, 985 (2015)

6. J. Hirvonen, J. Jokisalo, J. Heljo, and R. Kosonen, E3S Web Conf. 111, 03002 (2019)

7. É. Mata, A. S. Kalagasidis, and F. Johnsson, Renew. Sustain. Energy Rev. 93, 759 (2018)

8. M. S. Geraldi and E. Ghisi, Energy Build. 211, 109810 (2020)

9. C. Nägeli, M. Jakob, G. Catenazzi, and Y. Ostermeyer, Energy Build. 211, 109763 (2020)

10. N. H. Sandberg, O. Heidrich, R. Dawson, S. Dimitriou, T. Vimm-r, F. Filippidou, G. Stegnar, M. Šijanec Zavrl, and H. Brattebø, Energy Build. 132, 26 (2016)

11. T. Lang, Eur. Plan. Stud. 20, 1747 (2012)

12. S. Bouzarovski and S. Tirado Herrero, Eur. 
Urban Reg. Stud. 24, 69 (2017)

13. S. Huuhka, Build. Res. Inf. 3218, 1 (2015)

14. L. Castellazzi, P. Zangheri, and D. Paci, EUR 27722 EN 125 (2016)

15. J. Kurnitski, K. Kuusk, T. Tark, A. Uutar, T. Kalamees, and E. Pikas, Energy Build. 75, 51 (2014)

16. A. Uihlein and P. Eder, Energy Build. 42, 791 (2010)

17. L. Lihtmaa, D. B. Hess, and K. Leetmaa, Energy Policy (2018)

18. C. Turcu, Build. Res. Inf. 45, 892 (2017)

19. L. Sakkeus, J. McKibben, A. Puur, L. Rahnu, and L. Abuladze, in Est. Hum. Dev. Rep. 2016/2017, edited by Tiit Tammaru (Foundation Estonian Cooperation Assembly, 2017)

20. T. Tammaru, Urban Stud. 38, 1341 (2001)

21. K. Leetmaa, P. Metspalu, and T. Tammaru, Sustain. City IV Urban Regen. Sustain. 1, 621 (2006)

22. K. Kuusk and T. Kalamees, Energy Procedia 96, 628 (2016)

23. A. Cirman, S. Mandic, and J. Zoric, Urban Stud. 50, 3378 (2013)

24. D. S. Noonan, L.-H. C. Hsieh, and D. Matisoff, Energy Res. Soc. Sci. 10, 102 (2015)

25. S. Coltrane, D. Archer, and E. Aronson, Energy Policy 14, 133 (1986)

26. A. Ramos, A. Gago, X. Labandeira, and P. Linares, Energy Econ. 52, (2015)

27. C. Wilson, L. Crane, and G. Chryssochoidis, Energy Res. Soc. Sci. 7, 12 (2015)

28. Statistics Estonia, Dwellings in Estonia According to Census Data (2011)

29. K. Kuusk, Integrated Cost-Optimal Renovation of Apartment Buildings toward Nearly ZeroEnergy Buildings, Tallinn University of Technology, 2015

30. L. Lihtmaa, D. B. Hess, and K. Leetmaa, Energy Policy 119, (2018)

31. A. Hamburg and T. Kalamees, Energy Build. 199, 332 (2019)

32. T. Kalamees, K. Kuusk, E. Arumägi, and Ü. Alev, in Cost-Effective Energy Effic. Build. Retrofit. (Elsevier, 2017), pp. 405-454

33. K. Kuusk, T. Kalamees, S. Link, S. Ilomets, and A. Mikola, J. Civ. Eng. Manag. 23, 67 (2017)

34. K. Kuusk, P. Pihelo, and T. Kalamees, E3S Web Conf. 111, (2019)

35. T. Csoknyai, S. Hrabovszky-Horváth, Z. Georgiev, M. Jovanovic-Popovic, B. Stankovic, O. Villatoro, and G. Szendrő, Energy Build. 132, 39 (2016) 